\title{
EFFECT OF RICE-HUSK ASH ON EXCHANGE ACIDITY, GROWTH AND YIELD OF GROUNDNUT (ARACHIS HYPOGAEA L.) IN AN ACID ULTISOL.
}

\author{
D. O. NOTTIDGE, R. B. BALOGUN, and N. R. NJOKU
}

(Received 8 November, 2007; Revision Accepted 20 March, 2008)

\section{ABSTRACT}

Response of groundnut grown on acidic soil to rice-husk ash applied at $0,1,2,3$ and $4 \mathrm{t} \mathrm{ha}^{-1}$ was studied in two field experiments in 2005 and 2006 at Ishiagu in the derived savanna zone of southeast Nigeria. Treatments were fitted in a randomized complete block design (RCBD) replicated three times. Effects of treatments on some soil fertility and productivity parameters were evaluated. The rice-husk ash used contain $64.00 \mathrm{~g} \mathrm{~kg}^{-1} \mathrm{Ca}, 12.20 \mathrm{~g} \mathrm{~kg} \mathrm{Mg}^{-1} \mathrm{Mg}, 12.50 \mathrm{~g}$ $\mathrm{kg}^{-1} \mathrm{P}, 9.00 \mathrm{~g} \mathrm{~kg}^{-1} \mathrm{~K}, 2.10 \mathrm{~g} \mathrm{~kg}^{-1} \mathrm{~N}, 1.23 \mathrm{~g} \mathrm{~kg}^{-1}$ organic carbon and had a pH of 10.86 . Soil pH increased from initial values of 5.16 to 6.20 , while levels of exchangeable acidity correspondingly decreased from initial values of 0.80 to $0.26 \mathrm{cmol} \mathrm{kg}^{-1}$ with $3 \mathrm{t} \mathrm{ha}^{-1}$ applied rice-husk ash. Estimation of linear and quadratic curves respectively for soil $\mathrm{pH}$ and exchange acidity show values of $r^{2}=0.95$ for soil $p H$ and $R^{2}=0.98$ for exchange acidity. Significant increases $(P<$ $0.01)$ in soil $P, K$ and $C a$ status relate significantly $(P=0.05)$ to patterns of growth and kernel yield of the crop. The $3 t$ $\mathrm{ha}^{-1}$ rice-husk ash is recommended. No significant yield advantage was observed at $4 \mathrm{t} \mathrm{ha}^{-1}$.

KEY WORDS: Soil acidity, Rice-husk ash, Growth, Kernel yields groundnut, Southeast Nigeria.

\section{INTRODUCTION}

Soil infertility problems in humid tropical soils of southeast Nigeria are associated with low $\mathrm{pH}$, deficiency in soil organic matter, nitrogen and cations (Nottidge, 2005). Ultisols are highly weathered and leached. Consequently, they possess a much lower base status. The organic matter and cation exchange capacity are low and reflect the kaolinitic and oxide clay mineralogy (Enwezor, et al, 1989). The detrimental effects of high soil acidity are traceable largely to exchangeable aluminum levels. Hydrolysis of $\mathrm{Al}^{3+}$ generates $\mathrm{H}^{+}$and buffers the increase in soil solution $\mathrm{pH}$ (Havlin, et al, 2006). Soil pH will not increase until sufficient base is added to decrease the soluble $\mathrm{Al}^{3+}$. Anandan et al, in an experiment in an acid oxisol reported that an acid regime prevents the development of an effective legume-rhizobium symbiosis resulting in poor yields of peanut. Stubbiness of roots of some crops such as maize, groundnut and soybean, was ascribed to the toxic presence of soil exchangeable $\mathrm{Al}$, low $\mathrm{Ca}$ and $\mathrm{Mg}$ (Igbokwe et al, 1981; Anandan et al, 1985). Brady and Weil, (1999), concludes that a soil in the intermediate $\mathrm{pH}$ range $(6.0-6.5)$ presents the most satisfactory biological regime.

Although the problems of low $\mathrm{pH}$ and associated toxic levels of exchangeable $\mathrm{Al}$, deficiency of $\mathrm{Ca}$ and $\mathrm{Mg}$ can be ameliorated using calcitic limestone (Igbokwe et al, 1981; Anandan, et al, 1985), their high cost, unavailability, imbalanced nutrition and other problems associated with their use have often constituted a major constraint.

According to Opara-Nadi et al, (1989) the use of biological organic fertilizers such as wood ash for building up nutrient supply is important and requires intensive investigation which is being done in this work.

Wood ash contains various amounts of plant nutrients - $\mathrm{Ca}, \mathrm{Mg}, \mathrm{N}, \mathrm{P}, \mathrm{K}, \mathrm{Na}, \mathrm{Fe}, \mathrm{Mn}, \mathrm{Cu}$ and $\mathrm{Zn}$.
Their chemical compositions vary widely depending on the nature of plant material, the plant part and intensity of burning (Lallgee, 2000; Spaargaren, 1990, Nottidge, 2005).

The beneficial effect of wood ash in improving soil chemical properties, ear leaf nutrient composition, growth and grain yields of maize (Zea mays L.) had been established (Owolabi, et al, 2003; Nottidge et al, 2006; Nottidge et al, 2007). Liming improves nutrient availability and affects the soil microbial population and activities (Sartian, 1985). Crops may differ in their tolerance to soil acidity and their response to application of ash; thus, the results obtained with one crop may not be wholly applicable to other crops. This experiment was conducted to determine the effect of different levels of applied rice-husk ash on soil fertility status and productivity of groundnut in acid soil of Ishiagu in Ebonyi State.

\section{MATERIALS AND METHODS}

Two experiments, one in April 2005 and another in April 2006 were conducted at the Federal College of Agriculture, Ishiagu. Ishiagu is located on latitude $6^{\circ} 45^{\prime}$ $\mathrm{N}$ and longitude $8^{\circ} 30^{\prime} \mathrm{E}$ on 160 meters above sea level, with average annual rainfall of $1750 \mathrm{~mm}$. The soil at the experimental site was sandy clay loam and had the following characteristics: $\mathrm{pH} 5.16$; total Nitrogen $0.11 \%$; Organic carbon $1.18 \%$; available Phosphorus $26.00 \mathrm{mg}$ $\mathrm{kg}^{-1}$; and exchangeable Calcium, Magnesium and Potassium were 2.00, 1.60 and $0.21 \mathrm{cmol} \mathrm{kg}^{-1}$ respectively. The experimental sites were slashed, discploughed and harrowed by tractor. Seed beds $3 \mathrm{~m} \times 3 \mathrm{~m}$ were prepared manually using hoe and the different levels of rice-husk ash dust incinerated at the rice-mill dump site sieved to remove undesirable materials were incorporated at about $15 \mathrm{~cm}$ depth using hoe into the various plots at $0,1,2,3$ and $4 \mathrm{t} \mathrm{ha}^{-1}$. The chemical

D. O. Nottidge, Federal College of Agriculture Ishiagu, Ebonyi State. Nigeria.

R. B. Balogun, Federal College of Agriculture Ishiagu, Ebonyi State. Nigeria.

N. R. Njoku, National Root Crops Research Institute, Umudike. Abia State. Nigeria 
compositions of the rice- husk ash are shown in Table 1. The experimental design was a randomized complete block design (RCBD) replicated three times. Groundnut variety used was ICGVSM 85045 , planted at $0.60 \mathrm{~m} \mathrm{x}$ $0.25 \mathrm{~m}$ in $3 \mathrm{~m} \times 3 \mathrm{~m}$ plots. The sampling area was $2 \mathrm{~m} \times$ $2 \mathrm{~m}$.

\section{Soil and ash analysis}

Soil samples $(0-15 \mathrm{~cm}$ depth) were collected from each experimental unit at harvest of groundnut airdried and sieve to pass through 2-mm sieve. Soil $\mathrm{pH}$ was determined by the electrometric method using a soil water ratio of 1: 2.5. Organic carbon was determined by Walkely-Black titration method. Cations were leached with $1 \mathrm{~N} \mathrm{NH}_{4} \mathrm{OAc}$ at $\mathrm{pH}$ 7.0. Potassium and sodium were determined on flame photometer while calcium and magnesium were by EDTA titration. Exchange acidity was determined as described by Yuan (1959). Soil cation exchange capacity was measured by summation of the amounts of exchangeable cations and exchange acidity. Phosphorus was determined using Bray-1 method (Bray and Kurtz, 1945). Mechanical analysis was done by the hydrometer method after dispersing soil with sodium hexametaphosphate. Rice-husk ash was similarly analyzed.

\section{Statistical Analysis}

Data collected were subjected to analysis of variance (ANOVA). The two-year data were pooled after a non-significant test for heterogeneity of variances. The effect of rice-husk ash on some soil chemical properties, growth and kernel yield of groundnut was analyzed using curvilinear regression. Regression analysis was performed on treatment means averaged over replications (Gomez and Gomez, 1984). Regression equations were statistically compared by using the parameter estimates (Ratkowsky, 1983).

\section{RESULTS}

Results from initial soil analysis and field trials confirmed high levels of exchange acidity and low $\mathrm{Ca}$ status of the Ultisol at Ishiagu. The soil has a pH of 5.16. These characteristics are responsible for the response in growth and kernel yields of groundnut obtained in the field to varying levels of rice-husk ash.

Table 1: Chemical composition of rice-husk ash

\begin{tabular}{lc}
\hline Organic $\mathrm{C}\left(\mathrm{g} \mathrm{kg}^{-1}\right)$ & 1.23 \\
Nitrogen $\left(\mathrm{g} \mathrm{kg}^{-1}\right)$ & 2.10 \\
Phosphorus $\left(\mathrm{g} \mathrm{kg}^{-1}\right)$ & 12.50 \\
Potassium $\left(\mathrm{g} \mathrm{kg}^{-1}\right)$ & 9.00 \\
Calcium $\left(\mathrm{g} \mathrm{kg}^{-1}\right)$ & 64.00 \\
Magnesium $\left(\mathrm{g} \mathrm{kg}^{-1}\right)$ & 12.20 \\
$\mathrm{pH}$ & 10.86
\end{tabular}

\section{Effect of rice-husk ash on soil pH, exchange acidity and calcium status}

The response curves showing the effect of different levels of rice-husk ash on soil $\mathrm{pH}$, exchange acidity and calcium are presented in Figures 1, 2 and 3. Soil $\mathrm{pH}$ and exchangeable calcium and magnesium (Figure 4) increased linearly while levels of exchange acidity correspondingly decreased with rates of rice- husk ash applied. The prevailing strongly acidic condition in the no-ash treatment plots $\left(0 \mathrm{t} \mathrm{ha}^{-1}\right)$ were significantly reduced to slightly acid condition of $\mathrm{pH} 6.02$ with $3 \mathrm{t} \mathrm{ha}^{-1}$ application. The application of $4 \mathrm{t} \mathrm{ha}^{-1} \mathrm{did}$ not show any significant effect throughout the study period. The magnitude of coefficient of determination for the estimated response curves was highly significant $(P$ $=0.01$ ). 


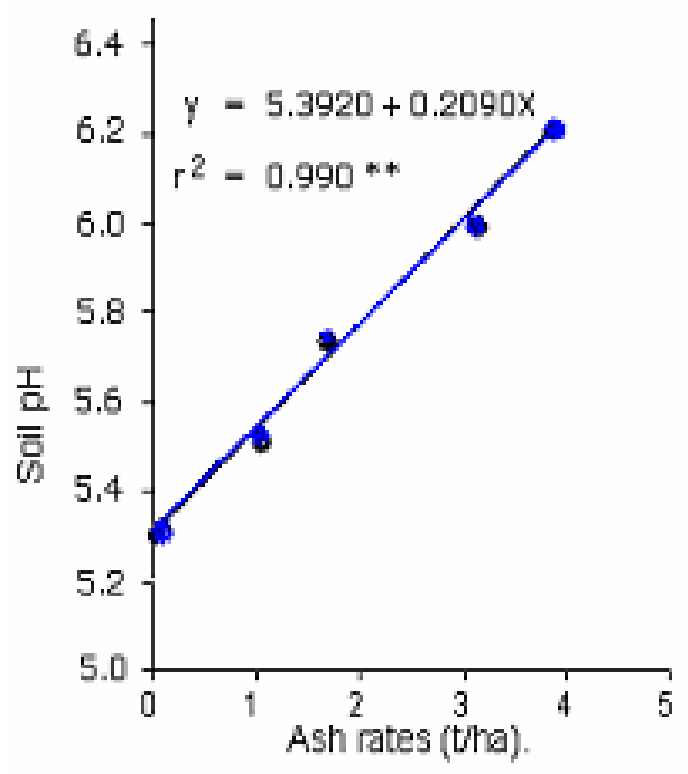

Figure 1: Effects of different levels of rice - husk ash on soilpH

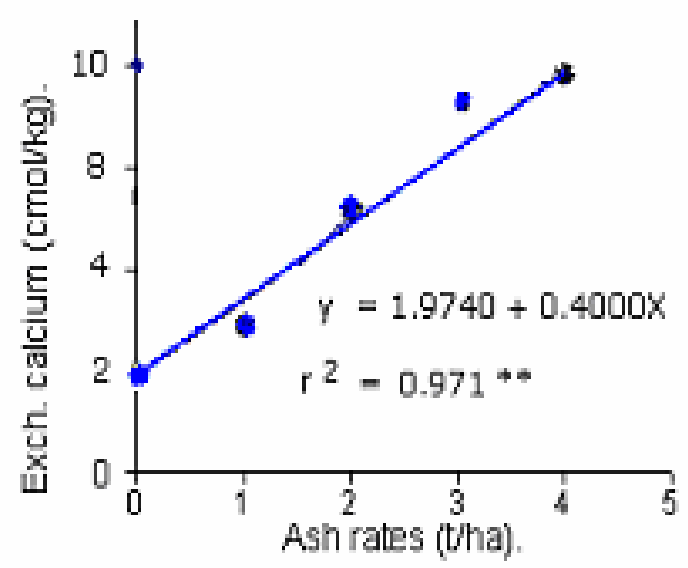

Figure 3: Effect of different levels of rice-rusk ash on soil exchangeable calcium.

\section{Effect on soil $P, K$ and ECEC status}

The estimated response curves depicting the effects of different levels of the ash on available $\mathrm{P}$ and $\mathrm{K}$ status are shown in Figures 5 and 6 . Although increases in the values of these elements were slight up to $3 \mathrm{tha}^{-1}$, significant response were however dictated in the values

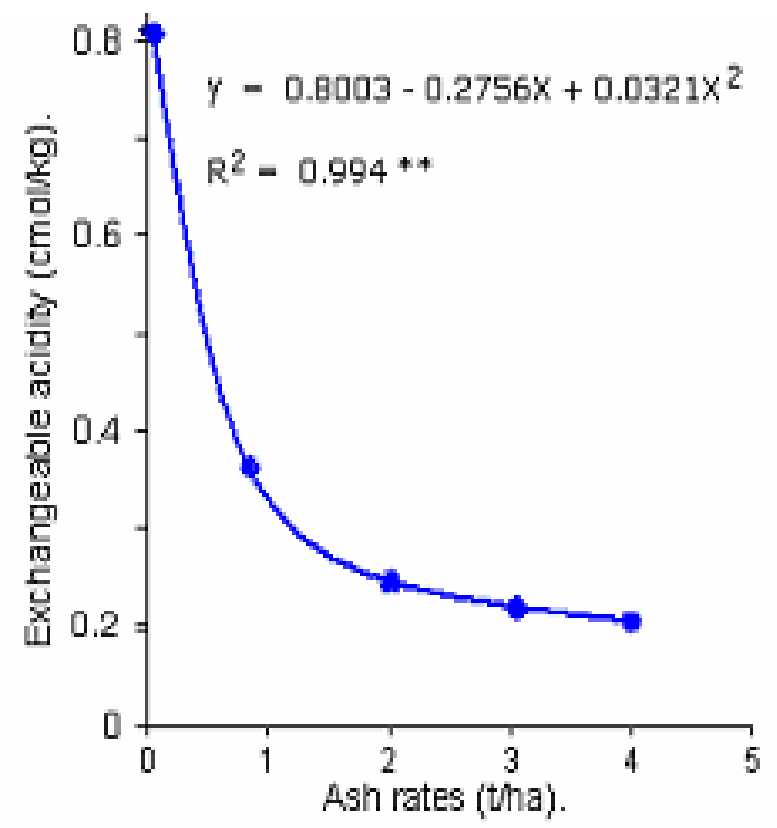

Figure 2: Effect of different levels of rice-husk ash on soil exchangeable acidity.

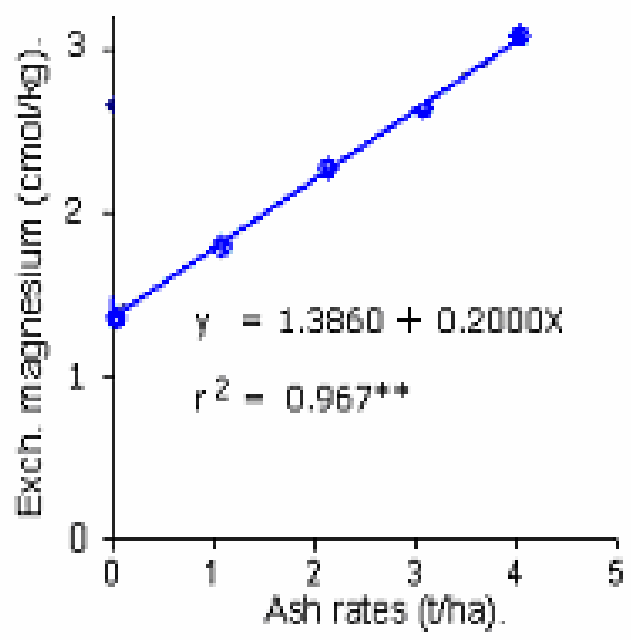

Figure 4: Effect of different levels of rice-husk ash an soil exchangeable magnesium.

of soil $\mathrm{K}$ at the application of $4 \mathrm{t} \mathrm{ha}^{-1}$ rice-husk ash (Figure 6). The rice-husk ash contains more $\mathrm{P}$ than $\mathrm{K}$ (Table 1). Also the effect of the rates of the ash on CEC was low although significant differences were detected from $3 \mathrm{t} \mathrm{ha}^{-1}$ (Figure 7). 


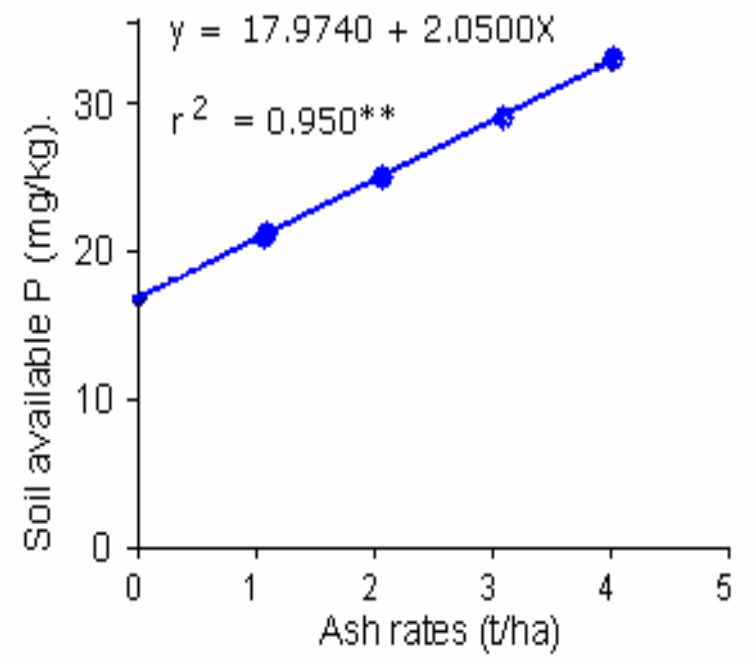

Figure 5: Effect of different levels of rice-husk ash on soil available phosphorus.

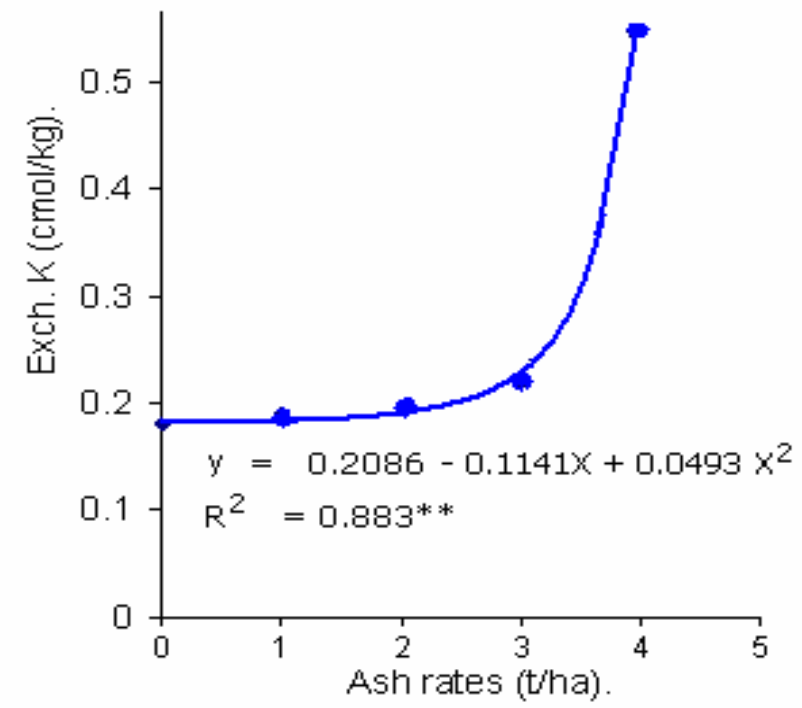

Figure 6: Effect of different levels of rice-husk ash on soil exchangeable potassium.

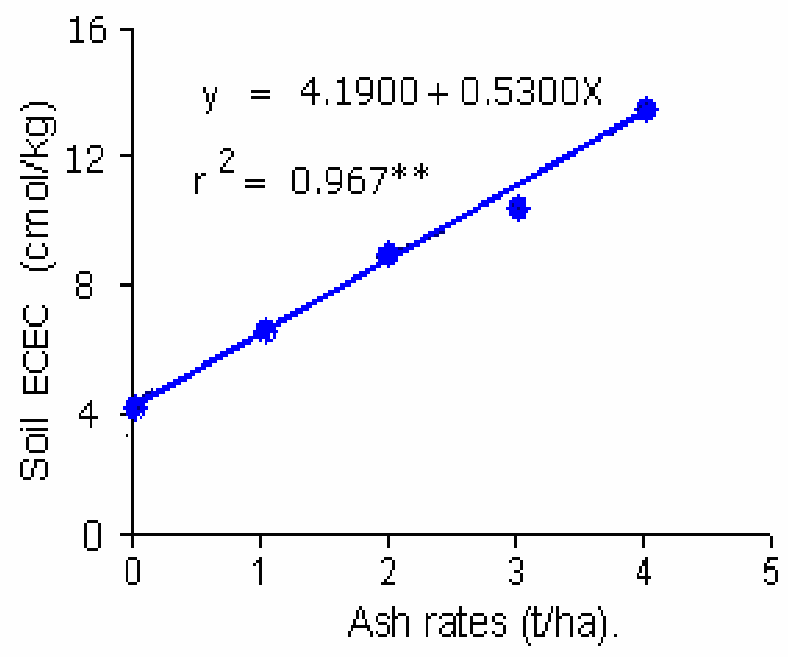

Figure 7: Effect of different levels of rice-husk ash on cation exchange capacity.

\section{Effect on shoot and kernel yields of groundnut}

Regression of shoot weight and kernel yields on rice-husk ash rates indicated that maximum shoot yield was achieved at $4 \mathrm{t} \mathrm{ha}^{-1}$ while kernel yield for both $3 \mathrm{t}$ and $4 \mathrm{tha}^{-1}$ ranked similarly (Figures 8 and 9 ). Both the observed and predicted response on the bases of buffer curves in Nottidge et al, (2006) on optimum rice-husk ash rates compared favorably showing the validity of the results.

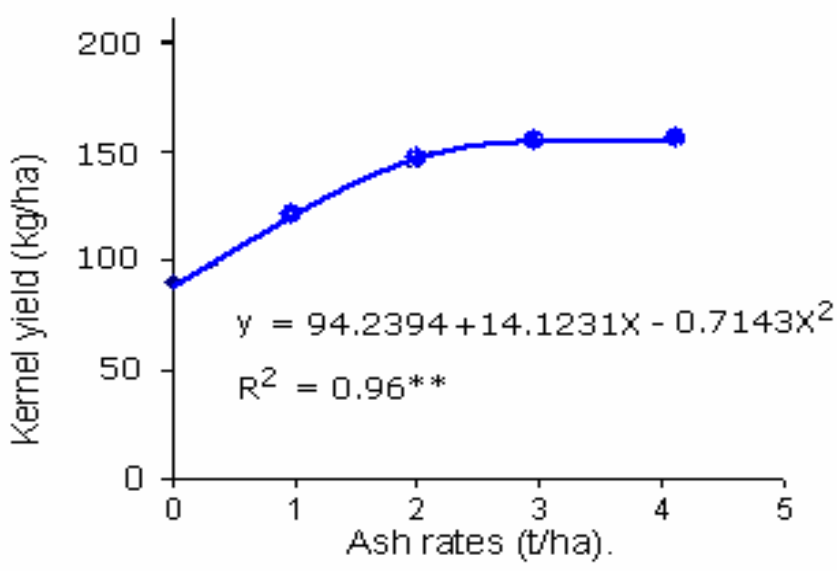

Figure 9: Effect of different levels of rice-husk ash on kernel yield of groundnut.

Figure 8: Effect of different levels of rice-husk ash on shoot dry weight of groundnut. 


\section{DISCUSSION}

In discussing the results obtained in this trial much reliance was placed on $\mathrm{pH}$ measurements. Firstly, it is easily and quickly determined electrometrically using a $\mathrm{pH}$ meter. More important is its susceptibility to certain broad correlations that are of great practical significant such as phosphate availability $(r=0.95)$. Thus, a great deal may be inferred regarding the physiological condition of a soil from its $\mathrm{pH}$ value, much more than from any other single analytical datum (Brady and Weil, 1999).

The soil studied is an Ultisol belonging to the siliceous mineralogical group and low in organic matter. Results from soil analysis confirmed high levels of exchange acidity and very low calcium status of the Ultisol. The soil is strongly acid ( $\mathrm{pH}$ 5.16). In this experiment, significant differences in all the parameters studied were obtained when rice-husk ash was applied at $3 \mathrm{t} \mathrm{ha}^{-1}$. The increase in soil $\mathrm{pH}$ from 5.16 to 6.22 (Figure 1) and reduction in the levels of exchangeable acidity from 0.81 to 0.21 (Figure 2 ) to crop tolerable level is commonly recognized (Nottidge, et al, 2006). The indirect effects of treatments on nutrient availability of $\mathrm{Ca}$, from 6.00 to $10.40 \mathrm{cmol} \mathrm{kg}^{-1}$; $\mathrm{Mg}$ from 4.00 to 6.40 $\mathrm{cmol} \mathrm{kg}^{-1}$, available $\mathrm{P}$ from 17.30 to $25.37 \mathrm{mg} \mathrm{kg}^{-1}$ and exchangeable $\mathrm{K}$ from 0.53 to $0.74 \mathrm{cmol} \mathrm{kg}^{-1}$ (Figures 5 and 6 ) and on the toxicity of certain elements were recognized (Nottidge, 2005).

In all the soil fertility indices studied, both the predicted and observed response of soil properties to applied rice-husk ash on the basis of the buffer curves compared favorably showing the validity of results. The results obtained in this trial are in agreement with that on wood ash on maize (Nottidge, et al, 2006). The increased soil $\mathrm{pH}$ could be ascribed to the calcium ions (Figure 3) released into the soil solution during the microbial decarboxylation of the ash (Natscher and Schwetnman, 1991). Exchangeable calcium correlated positively and significantly with soil $\mathrm{pH}(r=0.99)$.

Closely related to soil $\mathrm{pH}$ was the decrease in exchangeable acidity (Figure 2) to crop tolerant level. The toxicity of Al was associated with stubby roots only when the soil exchangeable acidity was $0.40 \mathrm{cmol} \mathrm{kg}^{-1}$. The decrease in exchange acidity could be ascribed to the precipitation of $\mathrm{Al}(\mathrm{OH})_{3}$ which occurred at the increased soil $\mathrm{pH}$. Marion et al, (1976) had shown that at $\mathrm{pH}$ above 6.00 aluminum exists in the soil as insoluble $\mathrm{Al}(\mathrm{OH})_{3}$. The $\mathrm{Al}$ toxicity of roots expressed as stubbiness is possibly due to its interference on the phosphorylation of sugars, as suggested by Clarkson, (1967).

Soil reaction plays an important role in nutrient availability and uptake. Phosphate is most frequently required for seed formation and maximally available in slightly acid condition but unavailable in strongly acid condition (Brady and Weil, 1999). Response of groundnut to these soil condition manifests in seed formation. Thus, from Figures 8 and 9, there was a significant increase in shoot and kernel yield from $3 \mathrm{tha}^{-}$ ${ }^{1}$ when compared with unlime treatment. Thus, rice-husk ash could serve as liming and fertilizer materials. The increase in kernel weight following addition of rice-husk ash as observed in this study is in agreement with those of Anandan et al, (1985). Increase in the yield of groundnut at $3 \mathrm{t} \mathrm{ha}^{-1}$ applied ash was obviously due to the suppression of toxic level of exchangeable Al as indicated by decrease in levels of exchange acidity and corresponding increase in availability of nutrients (Figures 5 and 6) at increased soil pH. Such decreased in exchangeable $\mathrm{Al}$ enabled better nodulation of the roots, resulting in higher yield.

\section{CONCLUSION}

Rice-husk ash is a plant residue and contains both macronutrients and micronutrients in varying amounts absorbed by the plant during normal growth. Rice-husk ash applied at $3 \mathrm{t} \mathrm{ha}^{-1}$ significantly increased soil $\mathrm{pH}$ and availability of nutrients to groundnut grown in acid soil. Higher rates of $4 \mathrm{t}$ ha- 1 applied ash had no significant yield advantage. It is recommended that nutrient impoverished and acid soils of southeast Nigeria be amended by incorporation of rice-husk ash at $3 \mathrm{t}$ ha- 1 to improve yields of groundnut for greater economic returns to the farmer.

\section{REFERENCES}

Anandan, K. M. S., Chandrasekaran, S. and Arunachlam, G., 1985. Effect of lime on exchangeable aluminum, nodulation and yield of peanut (Arachis hypogaea L.) in an acid Oxisol. Tropical Agriculture (Trinidad) Volume 62, pp39.

Brady, N. C. and Weil, R. R., 1999. The nature and properties of soils. $12^{\text {th }}$ edition. Prentice, Hall, New Jersey.

Bray, R. H. and Kurtz, L. T., 1945. Determination of total organic and available forms of phosphorus in soils. Soil Science 59: $39-45$.

Clarkson, D.T., 1967. Excess of aluminum, Plant and Soil. $27,344-347$.

Enwezor, W. O., Udo, E. J., Usoroh, N. J., Ayotade, K. A., Adepetu, J. A., Chude, V. O., and Udegbe, C. I., 1989. Fertilizer use and management practices for crops in Nigeria. 2: $52-56$.

Gomez, K. A. and Gomez, A. A., 1984. Statistical procedures for agricultural research. $2^{\text {nd }}$ edition. John Wiley and Sons, New York, NY.

Havlin, J. L., Beaton, J. D., Tisdale, S.L. and Nelson, W. L., 2006. Soil fertility and fertilizers - An Introduction to Nutrient Management, $7^{\text {th }}$ edition. $52-53$.

Igbokwe, M. C., Njoku, B. O. and Odurukwe, S. O., 1981. Liming effects on the response of maize to phosphate fertilizer on an Ultisol in Eastern Nigeria. Nigerian Journal of Soil Science. 11: $120-130$.

Lallgee, B., 2000. Fertilizer materials from sugar industry by-products. African Soils 31:215 -232.

Marion, G. M., Hendricks, D. M., Dult, G. R. and Fuller, W. H., 1976. Aluminum and silica solubility in seals. Soil Science. 121: 76 - 85 . 
Natschner, L. and Schwetmann, U., 1991. Proton buffering in organic horizons of acid forest soils. Geoderma 48: 93 - 106.

Nottidge, D.O., 2005. An investigation into the use of leguminous crop residues and wood ash for improving soil conditions and productivity of maize (Zea mays L.) in southeast Nigeria. Ph.D. Dissertation, Michael Okpara University of Agriculture. Umudike.

Nottidge, D. O., Ojeniyi, S. O. and Asawalam, D. O., 2006. Effect of different levels of wood ash on soil chemical properties in an acid Ultisol of southeast Nigeria. Nigerian Journal of Soil Science. 16: 109 - 114.

Nottidge, D. O., Ojeniyi, S.O. and Asawalam, D. O., 2007. Effect of different levels of wood ash on nutrient contents of maize (Zea mays L.) and grain yield in an acid Ultisol of Southeast Nigeria. Nigerian Journal of Soil Science. 17: 98 - 103.

Opara-Nadi, O. A., Ezumah, B. S. and Wogu, A., 1989. Organic manures and inorganic fertilizers added to an acid Ultisol in southeast Nigeria. Effects on soil chemical properties and nutrient loss. Proceedings $15^{\text {th }}$ Annual Conference of Soil Science Society of Nigeria. October $20-24$. Kaduna.

Owolabi, O., Adeleye, A., Oladejo, B. T. and Ojeniyi, S. O., 2003. Effect of wood ash on soil fertility and crop yield in Southwest Nigeria. Nigerian Journal of Soil Science 13: $55-60$.

Ratkowsky, D. H., 1983. Nonlinear regression modeling. Marcel Dekker, New York, NY.

Sartian, J. B., 1985. Effect of acidity and N-source on the growth and thatch accumulation Tifgreen Bermudagrass and on soil nutrient retention. Agronomy Journal 77: $33-36$.

Spaargaren, O., 1990. Africa land-acid soils network. In FBSRAM Newsletter. 16:4.

Yuan, T. L., 1959. Determination of exchangeable hydrogen in soil by a titration method. Soil Science 88: 164 - 167. 